\title{
RHETORICAL PATTERNS, VERB TENSE, AND VOICE IN CROSS DISCIPLINARY RESEARCH ARTICLE ABSTRACT
}

\author{
Sharifah Hanidar ${ }^{1}$ \\ ${ }^{1}$ English Study Program, Faculty of Cultural Sciences, Universitas Gadjah Mada \\ Email: dearhani@yahoo.com
}

\begin{abstract}
This article investigates research article abstracts in terms of their rhetorical patterns and the use of verb tenses and voice. A total of 40 abstracts were selected from four international journals in the fields of Biology, Mechanical Engineering, Linguistics, and Medicine. A four-move model was adopted from Hardjanto (1997) to analyze the structure of the abstracts. The results show that all the abstracts have Move 1, creating a research space; 70\% have Move 2, describing research procedure; $85 \%$ have Move 3, summarizing principal results; and $85 \%$ have Move 4, evaluating results. All the abstracts in medicine have Moves 1, 2, 3 and 4, whereas the most common pattern in Biology is Moves 1, 3 and 4, in Mechanical Engineering Moves 1, 2 and 3, and in Linguistics Moves 1, 2 and 4. This seems to suggest that there is a disciplinary variation in the structuring of RA abstracts in the four disciplines under investigation. With regard to the use of verb tense and voice in each move, the present tense and past tense in the active voice and the past tense in the passive voice were the most frequently used tenses. The present tense in the active voice was frequently used in Moves 1 and 4, while the past tense in the active voice was commonly used in Move 3 and the past tense in the passive voice was frequently found in Move 2. Furthermore, it was found that the present tense in the active voice was frequently used in Biology, Mechanical Engineering and Linguistics, whereas the past tense in the active voice occurred more frequently in Medicine, and the past tense in the passive voice was more frequently found in Mechanical Engineering than in other disciplines.
\end{abstract}

Keywords: move, research article abstracts, rhetorical patterns, tenses, voice,

\section{INTRODUCTION}

Almost every research article (RA) published in an international scientific journal begins with an abstract. It is usually the first thing that people would read before deciding to continue to read the article in its entirety. As 'an abbreviate, accurate, representation of a document' (ANSI, 1979:1), an abstract conveys to the readers what they should expect when reading the full article. Huckin (2001) defines the function of an abstract as a mini-text, a screening device, a preview, and an index. The conciseness and accuracy of an abstract enables readers to evaluate and decide whether it is significant or relevant for them to read further the full article or not.

One of the important features of an RA abstract is the organizational content of the text which is the division of the abstract into rhetorical moves representing the sections in it. According to Swales (2004:228), a move is a 'discoursal or rhetorical unit that performs a coherent communicative function in a written or spoken discourse.' There have been several move models proposed for the rhetorical structures of 
RA abstracts which vary in number and function. For example, Hyland (2000) proposed a five move structure consisting of Introduction, Purpose, Method, Product, and Conclusion. Santos (1996) also proposed a five-move model. Like Hyland the number of moves proposed by Santos is similar but the functions of the moves are slightly different. Santos' model consists of five functions: situating the research, presenting the research, describing the methodology, summarizing the results and discussing the research whereas Bhatia (1993), proposed a four-move model consisting of purpose, method, results, and conclusion. Hardjanto (1997) like Bhatia proposed a four-move model. However, the difference between Hardjanto's and Bhatia's models lies in the function of the moves. Hardjanto proposed four moves consisting of creating a research space, describing research procedure, summarizing principal results and evaluating results. By applying Hardjanto's model, the rhetorical organization of abstracts taken from four scientific disciplines were explored.

Another focus of examination of the RA abstracts is the linguistic features of the moves. Many researchers have discussed the verb tense and voice found in the moves in RA abstracts. According to Swales and Feak (2004), although the present tense is often used in opening statements and conclusions, sentences showing the results are often written in various tenses based on the various disciplines. In her study of verb forms used in medical abstracts, Salager-Meyer (1992) found that the present tense is used to emphasize the relevance of previous research, whereas the past tense is used to indicate the undeveloped nature of previous findings. Graetz as quoted in Hardjanto (1997:99) stated that:

The abstract is characterized by the use of past tense, third person, passive, and the non-use of negatives. It avoids subordinate clauses, uses phrases instead of clauses, words instead of phrases. It avoids abbreviation, jargons, symbols and other language shortcuts which might lead to confusion. It is written in tightly worded sentences, which avoids repetition, meaningless expressions, superlatives, adjectives, illustrations, preliminaries, descriptive details, examples, footnotes. In short it eliminates the redundancy which the skilled reader counts on finding in written language and which usually facilitates comprehension.

In contradiction to Graetz's statement, Hardjanto (1997) found that there is a high percentage of the present tense and active voice in the $50 \mathrm{RA}$ abstracts which he selected from five academic journals.

The purpose of the present study is to extend the study initiated by Hardjanto (1997), that is, to analyze the rhetorical patterns of the RA abstracts. Another focus of examination is the preferred tenses and voice used in each move of the abstracts. The analysis was limited to finite verbs. The nature of the research is exploratory because only 40 abstracts from four different disciplines were analyzed. Thus, the results might not be applicable to other fields of study.

\section{METHOD \\ The Corpus}

The corpus used in this research consists of 40 RA abstracts taken from four scientific journals published in 2013 in four disciplines:

Biology : The Plant Cell (TPC)
Engineering: Journal of Mechanical
Engineering (JME)
Linguistics : Journal of Pragmatics (JP)
Medicine $:$ The American Journal of
Medicine (TAJM)

The RA abstracts were chosen because of the following reasons. First, the abstracts were not taken from the indexing journals or abstracting journals but from primary journals which are reputable in the corresponding fields of study. Second, the selected journal should be listed in Thompson Reuters' 2010 Web of Science, Arts and Humanities Citation Index, Science Citation Index or Social Science Citation Index. Third, the selected abstracts were taken from articles reporting results of experimental research. Accordingly, 10 RA abstracts were selected from each journal, and coded according to their disciplines, BIO 01-10 for Biology, LING 01-10 for Linguistics, ENG 01-10 for Engineering, and MED 01-10 for Medicine. 


\section{Analysis of move structure}

Compared to the move models proposed by Bhatia (1993) and Santos (1996), Hardjanto's (1997) four move model is considered to be more suited for the analysis of the selected RA abstracts because it accomodates the moves found in the RA abstracts analyzed in the present research.

Below is the four move model proposed by Hardjanto (1997:116).

\begin{tabular}{|l|}
\hline Move 1: Creating a Research Space \\
Step 1: Establishing the field \\
Step 2: Preparing for present research \\
Step 3: Introducing present research \\
Move 2: Describing Research Procedure \\
Step 1: Presenting the data \\
Step 2: Describing the methods \\
Move 3: Summarizing Principal Results \\
Move 4: Evaluating Results \\
Step 1: Drawing conclusion \\
Step 2: Comparing results \\
Step 3: Indicating discussion \\
\hline
\end{tabular}

With the above model used as the framework, each move in the RA abstracts was coded M1 for Move 1, M2 for Move 2, M3 for Move 3, and M4 for Move 4. The aim of the analysis is to see whether all the RA abstracts have the four move structure. Kanoksilapatham (2005) suggests that if a move occurs in every RA abstract (100\%), it is regarded as obligatory, if the occurence of the move ranges from $60-99 \%$, it is considered as a conventional move but if the occurence is less than $60 \%$, it is considered as an optional move. This criteria was used to determine whether a move in the RA abstracts in various disciplines is obligatory, conventional or optional by recording the frequency of a particular move.

The following are two examples of RA abstracts that have been coded. The first abstract is taken from a medical RA abstract (MED 10) which conforms to Hardjanto's (1997) four-move model: M1-M2-M3-M4. The second abstract is taken from a Biology RA abstract (BIO 06) which has a threemove structure: M1-M3-M4. 


\section{Example 1}

Health Consequences among Subjects Involved in Gulf Oil Spill Clean-up Activities

(MED 10)

\section{$<$ M1 $>$ Creating a Research Space}

Oil spills are known to affect human health through the exposure of inherent hazardous chemicals such as para-phenols and volatile benzene. This study assessed the adverse health effects of the Gulf oil spill exposure in subjects participating in the clean-up activity along the coast of Louisiana.

\section{$<$ M2 $>$ Describing Research Procedure}

This retrospective study included subjects that had been exposed and unexposed to the oil spill and dispersant. Using medical charts, clinical data including white blood cell count, platelets count, hemoglobin, hematocrit, blood urea nitrogen, creatinine, alkaline phosphatase (ALP), aspartate amino transferase (AST), alanine amino transferase (ALT), and somatic symptom complaints by the subjects were reviewed and analyzed.

\section{$<$ M3 $>$ Summarizing Principal Results}

A total of 247 subjects (oil spill exposed, $n=117$ and unexposed, $n=130$ ) were included. Hematologic analysis showed that platelet counts $\left(\times 10^{3}\right.$ per $\left.\mu \mathrm{L}\right)$ were significantly decreased in the exposed group compared with those in the group unexposed to the oil spill $(252.1 \pm 51.8 \mathrm{vs}$ $269.6 \pm 77.3, P=.024)$. Conversely, the hemoglobin (g per dL) and hematocrit (\%) levels were significantly increased among oil spill-exposed subjects compared with the unexposed subjects $(P=.000)$. Similarly, oil spill-exposed subjects had significantly higher levels of ALP $(76.3 \pm$ 21.3 vs $61.2 \pm 26.9 \mathrm{IU} / \mathrm{L}, P=.000)$, AST $(31.0 \pm 26.3$ vs $22.8 \pm 11.8 \mathrm{IU} / \mathrm{L}, P=.004)$, and ALT $(34.8 \pm 26.6$ vs $29.8 \pm 27 \mathrm{IU} / \mathrm{L}, P=.054)$ compared with the unexposed subjects.

$<$ M4 $>$ Evaluating Results

The results of this study indicate that clean-up workers exposed to the oil spill and dispersant experienced significantly altered blood profiles, liver enzymes, and somatic symptoms. 


\section{Example 2}

\section{Formation of a Functional Maize Centromere after Loss of Centromeric Sequences and Gain of EctopicSequences (BIO 06)}

\section{$<$ M1 $>$ Creating a Research Space}

The maize (Zea mays) B centromere is composed of B centromere-specific repeats (ZmBs), centromere-specific satellite repeats (CentC), and centromeric retrotransposons of maize (CRM). Here we describe a newly formed $\mathrm{B}$ centromere in maize, which has lost CentC sequences and has dramatically reduced CRM and $\mathrm{ZmBs}$ sequences, but still retains the molecular features of functional centromeres, such as CENH3, H2A phosphorylation at Thr-133, H3 phosphorylation at Ser-10, and Thr-3 immunostaining signals.

\section{$<$ M3 $>$ Summarizing Principal Results}

This new centromere is stable and can be transmitted to offspring through meiosis. Anti-CENH3 chromatin immunoprecipitation sequencing revealed that a $723-\mathrm{kb}$ region from the short arm of chromosome 9 (9S) was involved in the formation of the new centromere. The 723-kb region, which is gene poor and enriched for transposons, contains two abundant DNA motifs. Genes in the new centromere region are still transcribed. The original $723-\mathrm{kb}$ region showed a higher DNA methylation level compared with native centromeres but was not significantly changed when it was involved in new centromere formation.

\section{$<$ M4> Evaluating Results}

Our results indicate that functional centromeres may be formed without the known centromerespecific sequences, yet the maintenance of a high DNA methylation level seems to be crucial for the proper function of a new centromere.

\section{Analysis of Verb Tense and Voice in the Moves}

Swales (1990) indicates that different tenses are used to mark different moves in abstracts because they show the different functions of the moves. Malcolm (1987) in line with Swales (1990) suggests that the choice of a verb tense is mainly based on their rhetorical functions in research articles. Thus, the purpose of this study is to analyze the tenses and voice of finite verbs used in different moves of the abstracts with regard to their frequency, distribution and functions. The tenses and voice of finite verbs in each move of the abstracts were studied and tagged to note their frequency and distribution.

\section{Results and Discussion}

As mentioned previously, all the 40 abstracts in the corpus were analyzed using Hardjanto's (1997) four-move model for their rhetorical patterns. Table 1 summarizes the results of the analysis of Biology RA abstracts. 
Table 1

Rhetorical Patterns of Biology Abstracts

\begin{tabular}{|c|c|c|c|c|c|c|c|c|}
\hline Abstract & $<$ M1 $>$ & $<\mathbf{M} 2>$ & $<$ M3 $>$ & $<$ M4> & $<$ M1 $>$ & $<\mathbf{M} 2>$ & $<$ M3 $>$ & $<$ M4> \\
\hline BIO 01 & $<\mathrm{M} 1>$ & & $<\mathrm{M} 3>$ & $<\mathrm{M} 4>$ & & & & \\
\hline BIO 02 & $<\mathrm{M} 1>$ & & $<\mathrm{M} 3>$ & $<\mathrm{M} 4>$ & & & & \\
\hline BIO 03 & $<\mathrm{M} 1>$ & & $<\mathrm{M} 3>$ & $<\mathrm{M} 4>$ & & & & \\
\hline BIO 04 & $<\mathrm{M} 1>$ & & $<\mathrm{M} 3>$ & $<\mathrm{M} 4>$ & & & & \\
\hline $\mathrm{BIO} 05$ & $<\mathrm{M} 1>$ & & $<\mathrm{M} 3>$ & $<\mathrm{M} 4>$ & & & $<\mathrm{M} 3>$ & \\
\hline BIO 06 & $<\mathrm{M} 1>$ & & $<\mathrm{M} 3>$ & $<\mathrm{M} 4>$ & & & & \\
\hline BIO 07 & $<\mathrm{M} 1>$ & $<\mathrm{M} 2>$ & $<\mathrm{M} 3>$ & & & & & \\
\hline BIO 08 & $<\mathrm{M} 1>$ & & $<\mathrm{M} 3>$ & $<\mathrm{M} 4>$ & & & & \\
\hline BIO 09 & $<\mathrm{M} 1>$ & & $<\mathrm{M} 3>$ & $<\mathrm{M} 4>$ & & & & \\
\hline BIO 10 & $<\mathrm{M} 1>$ & $<\mathrm{M} 2>$ & $<\mathrm{M} 3>$ & $<\mathrm{M} 4>$ & & & & \\
\hline Total of occurrences & $100 \%$ & $20 \%$ & $100 \%$ & $90 \%$ & & & $10 \%$ & \\
\hline
\end{tabular}

Table 1 shows 4 different move patterns found in Biology RA abstracts. There are RA abstracts that use a 3 move structure, and a 4 move structure. However there are also RA abstracts that use a 5 move structure with a cyclical pattern. In the cyclical pattern a move re-occurs in the RA abstract.

The table also shows that 7 abstracts (70\%) contain three moves (Moves 1, 3 and 4), one abstract (10\%) contains all the 4 moves in the order of M1-M2-M3-M4, one abstract (10\%) contains three moves (Moves 1, 3 and 4) and 1 abstract $(10 \%)$ has three moves (moves 1, 3 and 4 ), one of which (Move 3) is used again after Move 4 (cycled).

Table 1 reveals that all the RA abstracts open with Move 1: Creating a Research Space (100\%). The least frequently used move in the RA abstracts is Move 2 which describes the research procedure including presenting the data and describing the methods. It is only used in $20 \%$ of the RA abstracts. This suggests that describing research procedure is not emphasized in the abstracts in this discipline. The writers did not write the procedure of the research in the abstracts but directly summarized the results followed by an evaluation of the results. In one abstract (BIO 05), Move 3 is used cyclically which means that it reoccurs in the abstract. Most of the RA abstracts close with move 4: Evaluating Results.

The results in Table 1 show that creating a research space (M1), summarizing principal result (M3) and evaluating the result (M4) are the obligatory moves in Biology RA abstracts. Although there is a variety of move patterns, the most frequent pattern used is M1-M3-M4. 80\% of the RA abstracts used this pattern.

To determine whether a move is obligatory, conventional or optional, the frequency of a particular move is counted. In line with Kanoksilapatham (2005) it can be concluded that Move 1: Creating a research Space and Move 3: Summarizing Principal Results are considered obligatory because their occurences are $100 \%$, and Move 4: Evaluating Results is considered conventional in Biology RA abstracts because the occurrence is more than $60 \%$. However Move 2: Describing Research Procedure is considered as an optional move because its occurrence is less than $60 \%$. 
Table 2

Rhetorical Patterns of Mechanical Engineering Abstracts

\begin{tabular}{|c|c|c|c|c|c|c|c|c|}
\hline JME & $<$ M1 $>$ & $<\mathbf{M} 2>$ & $<$ M3 $>$ & $<$ M4 $>$ & $<$ M1 $>$ & $<\mathbf{M} 2>$ & $<$ M3 $>$ & $<$ M4 $>$ \\
\hline ENG 01 & $<\mathrm{M} 1>$ & & $<\mathrm{M} 3>$ & & & & & \\
\hline ENG 02 & $<\mathrm{M} 1>$ & $<\mathrm{M} 2>$ & $<\mathrm{M} 3>$ & $<\mathrm{M} 4>$ & & & & \\
\hline ENG 03 & $<\mathrm{M} 1>$ & $<\mathrm{M} 2>$ & $<\mathrm{M} 3>$ & $<\mathrm{M} 4>$ & & & & \\
\hline ENG 04 & $<\mathrm{M} 1>$ & $<\mathrm{M} 2>$ & $<\mathrm{M} 3>$ & $<\mathrm{M} 4>$ & & & & \\
\hline ENG 05 & $<\mathrm{M} 1>$ & & & $<\mathrm{M} 4>$ & & $<\mathrm{M} 2>$ & $<\mathrm{M} 3>$ & \\
\hline ENG 06 & $<\mathrm{M} 1>$ & $<\mathrm{M} 2>$ & $<\mathrm{M} 3>$ & & & & & \\
\hline ENG 07 & $<\mathrm{M} 1>$ & $<\mathrm{M} 2>$ & $<\mathrm{M} 3>$ & & & & & \\
\hline ENG 08 & $<\mathrm{M} 1>$ & $<\mathrm{M} 2>$ & $<\mathrm{M} 3>$ & & & & & \\
\hline ENG 09 & $<\mathrm{M} 1>$ & $<\mathrm{M} 2>$ & $<\mathrm{M} 3>$ & & & & & \\
\hline ENG 10 & $<\mathrm{M} 1>$ & $<\mathrm{M} 2>$ & $<\mathrm{M} 3>$ & $<\mathrm{M} 4>$ & & & & \\
\hline Total of occurrences & $100 \%$ & $80 \%$ & $90 \%$ & $50 \%$ & & $10 \%$ & $10 \%$ & \\
\hline
\end{tabular}

Table 2 presents the moves found in RA abstracts from Mechanical Engineering. The table demonstrates that $40 \%$ of the abstracts consists of all the four moves while the other $60 \%$ does not conform to Hardjanto's (1979) proposed move pattern but has different models of move patterns. An analysis of the move structure of each abstract in the corpus reveals that the abstracts show four different move structures. Four abstracts (40\%) contain all the four moves in the order of M1-M2M3-M4, four other abstracts (40\%) have three moves (Moves 1, 2 and 3), one abstract (10\%) has four moves with a different order which is M1M4-M2-M3, and one abstract (10\%) contains two moves (Moves 1 and 3).
The results seem to suggest that abstracts in Mechanical Engineering tend to have one obligatory move, which is Move 1: Creating a research Space with 100\% occurrences in the abstracts. Whereas Move 2: Describing Research Procedure with $80 \%$ occurrences and Move 3: Summarizing Principal Results with 90\% occurrences are considered as conventional moves. However Move 4: Evaluating Results has the lowest frequency with $50 \%$ occurrences making it an optional move in Mechanical Engineering RA abstracts. This suggests that presenting result evaluation may not be important in Mechanical Engineering abstracts.

Table 3

Rhetorical Patterns of Linguistics Abstracts

\begin{tabular}{|c|c|c|c|c|c|c|c|c|}
\hline JP & $<\mathbf{M} 1>$ & $<\mathbf{M} 2>$ & $<$ M3 $>$ & $<$ M4 > & $<\mathbf{M 1}>$ & $<\mathbf{M} 2>$ & $<$ M3 $>$ & $<$ M4 $>$ \\
\hline LIN 01 & $<\mathrm{M} 1>$ & & & $<\mathrm{M} 4>$ & & & & \\
\hline LIN 02 & $<\mathrm{M} 1>$ & $<\mathrm{M} 2>$ & & $<\mathrm{M} 4>$ & & & $<\mathrm{M} 3>$ & $<\mathrm{M} 4>$ \\
\hline LIN 03 & $<\mathrm{M} 1>$ & $<\mathrm{M} 2>$ & $<\mathrm{M} 3>$ & $<\mathrm{M} 4>$ & & & & \\
\hline LIN 04 & $<\mathrm{M} 1>$ & $<\mathrm{M} 2>$ & $<\mathrm{M} 3>$ & $<\mathrm{M} 4>$ & & & & \\
\hline LIN 05 & $<\mathrm{M} 1>$ & & $<\mathrm{M} 3>$ & $<\mathrm{M} 4>$ & & & & \\
\hline LIN 06 & $<\mathrm{M} 1>$ & $<\mathrm{M} 2>$ & $<\mathrm{M} 3>$ & $<\mathrm{M} 4>$ & & & & \\
\hline LIN 07 & $<\mathrm{M} 1>$ & $<\mathrm{M} 2>$ & & $<\mathrm{M} 4>$ & & & & \\
\hline LIN 08 & $<\mathrm{M} 1>$ & $<\mathrm{M} 2>$ & $<\mathrm{M} 3>$ & $<\mathrm{M} 4>$ & & & & \\
\hline LIN 09 & $<\mathrm{M} 1>$ & $<\mathrm{M} 2>$ & & $<\mathrm{M} 4>$ & & & & \\
\hline LIN 10 & $<\mathrm{M} 1>$ & $<\mathrm{M} 2>$ & & $<\mathrm{M} 4>$ & & & & \\
\hline Total of occurrences & $100 \%$ & $80 \%$ & $50 \%$ & $100 \%$ & & & $10 \%$ & $10 \%$ \\
\hline
\end{tabular}


Table 3 indicates that the abstracts have a variety of move patterns. Not all the abstracts take the move pattern proposed by Hardjanto (1997). Although some of the abstracts have four move patterns, they do not follow the moves consecutively. Four abstracts $(40 \%)$ have four moves in the order of M1-M2-M3-M4, four other abstracts (40\%) have three moves (M1, M2 and M4), and one abstract (10\%) contains two moves (M1 and M4). In one abstract, (LIN 02), Move 4 is used cyclically (M1-M2-M4-M3-M4) which means that it reoccurs in the abstract.
The results show that abstracts in Linguistics tend to have two obligatory moves; Move 1: Creating a Research Space with 100\% occurrences, and Move 4: Evaluating Results with 100\% occurrences. Move 2: Describing Research Procedure with $80 \%$ occurrences, is a conventional move because the frequency of occurrence is greater than $60 \%$. The table also shows that Move 3: Summarizing Principal Results has a low frequency of occurrence, less than $60 \%$ making it an optional move in the RA abstracts. This suggests that summarizing the results is not given priority in Linguistics RA abstracts.

Table 4

Rhetorical Patterns of Medical Abstracts

\begin{tabular}{|c|c|c|c|c|c|c|c|c|}
\hline TAJM & $<$ M1 $>$ & $<$ M2> & $<$ M3 $>$ & $<$ M4 $>$ & $<$ M1 $>$ & $<$ M2 $>$ & $<$ M3 $>$ & $<$ M4 $>$ \\
\hline MED 01 & $<\mathrm{M} 1>$ & $<\mathrm{M} 2>$ & $<\mathrm{M} 3>$ & $<\mathrm{M} 4>$ & & & & \\
\hline MED 02 & $<\mathrm{M} 1>$ & $<\mathrm{M} 2>$ & $<\mathrm{M} 3>$ & $<\mathrm{M} 4>$ & & & & \\
\hline MED 03 & $<\mathrm{M} 1>$ & $<\mathrm{M} 2>$ & $<\mathrm{M} 3>$ & $<\mathrm{M} 4>$ & & & & \\
\hline MED 04 & $<\mathrm{M} 1>$ & $<\mathrm{M} 2>$ & $<\mathrm{M} 3>$ & $<\mathrm{M} 4>$ & & & & \\
\hline MED 05 & $<\mathrm{M} 1>$ & $<\mathrm{M} 2>$ & $<\mathrm{M} 3>$ & $<\mathrm{M} 4>$ & & & & \\
\hline MED 06 & $<\mathrm{M} 1>$ & $<\mathrm{M} 2>$ & $<\mathrm{M} 3>$ & $<\mathrm{M} 4>$ & & & & \\
\hline MED 07 & $<\mathrm{M} 1>$ & $<\mathrm{M} 2>$ & $<\mathrm{M} 3>$ & $<\mathrm{M} 4>$ & & & & \\
\hline MED 08 & $<\mathrm{M} 1>$ & $<\mathrm{M} 2>$ & $<\mathrm{M} 3>$ & $<\mathrm{M} 4>$ & & & & \\
\hline MED 09 & $<\mathrm{M} 1>$ & $<\mathrm{M} 2>$ & $<\mathrm{M} 3>$ & $<\mathrm{M} 4>$ & & & & \\
\hline MED 10 & $<\mathrm{M} 1>$ & $<\mathrm{M} 2>$ & $<\mathrm{M} 3>$ & $<\mathrm{M} 4>$ & & & & \\
\hline Total of Occurrences & $100 \%$ & $100 \%$ & $100 \%$ & $100 \%$ & & & & \\
\hline
\end{tabular}

It is indicated in table 4 that all the RA abstracts conform to the M1-M2-M3-M4 move pattern: creating a Research Space, Describing Research Procedure, Summarizing Principal Results and Evaluating Results proposed by Hardjanto (1979). Based on their frequency, all the moves are obligatory moves because of the $100 \%$ occurences. It can then be concluded that it is obligatory that RA abstracts from Medicine journals have all the moves mentioned.

Based on the analysis of all the RA abstracts, Move 1: Creating a Research Space is obligatory for all the disciplines (100\%); Move 2: Describing Research Procedures is obligatory for Medicine $(100 \%)$, conventional for two other diciplines: Engineering (80\%), and Linguistics (80\%) and optional for Biology (20\%). Move 3: Summarizing Principal Results is obligatory for RA abstracts in
2 disciplines namely Biology (100\%) and Medicine (100\%), conventional for Engineering (90\%), and optional for Linguistics (50\%) RA abstracts; Move 4: Evaluating Results is obligatory for RA abstracts in 2 disciplines namely Linguistics (100\%) and Medicine (100\%), conventional for Biology (90\%), and optional for Engineering (50\%) RA abstracts.

The result of the analysis of the move structure reveals that Move 1 is obligatory for all disciplines, Move 2 is obligatory only for Medicine but is absent in the other disciplines. Describing research procedure is not considered substantial by the other three diciplines, Biology, Mecahnical Engineering and Linguistics. Move 3 is obligatory for Biology and Medicine, and Move 4 is obligatory for Medicine and Linguistics. Thus the analysis reveals that there is a disciplinary variation in the rhetorical pattern of each discipline. 


\section{VERB TENSE AND VOICE IN RA ABSTRACTS}

This section presents the results of the analysis of the use of verb tense and voice in RA abstracts found in four disciplines; Biology, Mechanical
Engineering, Linguistics and Medicine. The first step in the analysis was to count the number of words found in each move of the four disciplines as shown in table 5 in order to be able to determine the distribution of the finite verbs.

Table 5

The total number of words in each move of the four disciplines

\begin{tabular}{|c|c|c|c|c|c|}
\hline \multirow{2}{*}{ Moves } & \multicolumn{4}{|c|}{ Disciplines } & \multirow[b]{2}{*}{ Total words } \\
\hline & Biology & Mechanical Engineering & Linguistics & Medicine & \\
\hline Move 1 & 706 & 913 & 341 & 508 & 2,468 \\
\hline Move 2 & 58 & 374 & 364 & 789 & 1.585 \\
\hline Move 3 & 902 & 477 & 505 & 1,171 & 3,055 \\
\hline Total words & 2,038 & 1,897 & 1,679 & 2,873 & 8,487 \\
\hline
\end{tabular}

It can be seen from the data presented in table 5 that the total number of words of the RA abstracts from each discipline is not the same. Medicine has the highest number of words which is 2,873 words compared to Biology, 2,038 words, Mechanical Engineering, 1,897 words and Medicine, 2,873 words. Due to the fact that the lengths of the abstracts of each discipline are not the same, the analysis of the frequency and distribution of tense and voice is not based on percentage but on the number of finite verbs per 1,000 words.

The total number of finite verbs identified and counted in the four disciplines is a total of 544 finite verbs. The frequency of the finite verbs was counted to determine the variations found in all the disciplines.

Table 6

Distribution of finite verbs by Discipline

\begin{tabular}{llllll}
\hline \multirow{2}{*}{ Moves } & \multicolumn{5}{c}{ Disciplines } \\
\cline { 2 - 6 } & \multicolumn{1}{c}{ Biology } & Mechanical Engineering & Linguistics & Medicine & Total \\
\hline Move 1 & 20.12 & 31.63 & 13.70 & 10.79 & 76.24 \\
Move 2 & 1.47 & 13.18 & 16.68 & 14.27 & 45.60 \\
Move 3 & 33.37 & 15.29 & 22.04 & 22.28 & 92.98 \\
\hline $\begin{array}{l}\text { Total Finite verbs } \\
\text { per 1,000 words }\end{array}$ & 66.74 & 63.26 & 73.26 & 57.43 & 260.69 \\
\hline
\end{tabular}

Table 6 shows the distribution of finite verbs per 1,000 words across disciplines. The highest frequency of the finite verbs is found in Linguistics RA abstracts with 73.26 occurrences per 1,000 words, whereas RA abstracts in Biology have
66.74 finite verbs per 1,000 words, Mechanical Engineering has 63.26 finite verbs per 1,000 words and Medicine has 57.43 finite verbs per 1,000 words. 
Table 7

Frequency and Distribution of Verb Tense and Voice by Discipline

\begin{tabular}{|c|c|c|c|c|c|}
\hline Finite Verbs & Biology & $\begin{array}{l}\text { Mechanical } \\
\text { Engineering }\end{array}$ & Linguistics & Medicine & Total \\
\hline \multicolumn{6}{|l|}{ Active } \\
\hline Present & 25.52 & 27.41 & 35.14 & 7.66 & 95.73 \\
\hline Past & 17.66 & 4.22 & 6.55 & 27.50 & 55.93 \\
\hline Perfect* & 3.43 & 1.06 & 1.19 & 2.43 & 8.11 \\
\hline Other** & 0 & 0 & 0 & 0 & 0 \\
\hline $\begin{array}{l}\text { Subtotal finite verbs per } \\
1,000 \text { words }\end{array}$ & 46.61 & 32.69 & 42.88 & 37.59 & 159.77 \\
\hline \multicolumn{6}{|l|}{ Passive } \\
\hline Present & 9.81 & 8.43 & 13.71 & 1.39 & 33.34 \\
\hline Past & 5.41 & 16.34 & 8.93 & 14.62 & 45.30 \\
\hline Perfect* & 0 & 0.53 & 0 & 0 & 0.53 \\
\hline Other** & 0 & 0 & 0 & 0 & 0 \\
\hline $\begin{array}{l}\text { Subtotal finite verbs per } \\
1,000 \text { words }\end{array}$ & 15.22 & 25.30 & 22.64 & 16.01 & 79.17 \\
\hline \multicolumn{6}{|l|}{ Modal } \\
\hline Active & 3.93 & 0 & 4.76 & 3.48 & 12.17 \\
\hline Passive & 0.98 & 5.27 & 2.98 & 0.35 & 9.58 \\
\hline $\begin{array}{l}\text { Subtotal finite verbs per } \\
1,000 \text { words }\end{array}$ & 4.91 & 5.27 & 7.74 & 3.83 & 21.75 \\
\hline $\begin{array}{l}\text { Total finite verbs per } \\
1,000 \text { words }\end{array}$ & 66.74 & 63.26 & 73.26 & 57.43 & 260.69 \\
\hline
\end{tabular}

Note:

*Perfect $=$ Present Perfect

**Other $=$ Progressive and Past Perfect

The data in table 7 shows that the highest frequency of present tense in the active voice is found in Linguistics RA abstracts with 35.14 occurrences per 1,000 words. The second frequent use of present tense in the active voice is found in Mechanical Engineering RA abstracts with 27.41 occurrences per 1,000 words and in Biology RA abstracts with 25.52 occurrences per 1,000 words. Whereas the highest frequency of past tense in the active voice is found in Medical RA abstracts with 27.50 occurrences per 1,000 words. 
Table 8

Frequency and distribution of tense and voice use across the four moves

\begin{tabular}{llllll}
\hline \multicolumn{1}{c}{ Finite Verbs } & Move 1 & Move 2 & Move 3 & Move 4 & \\
\hline Active & & & & & \\
\hline Present & 34.44 & 6.94 & 15.06 & 31.18 & 87.62 \\
Past & 6.48 & 9.46 & 30.11 & 7.98 & 54.03 \\
Perfect* & 5.27 & 0 & 1.64 & 0 & 6.91 \\
Other** & 0 & 0 & 0 & 0 & 0 \\
\hline Subtotal finite verbs per 1,000 words & $\mathbf{4 6 . 1 9}$ & $\mathbf{1 6 . 4 0}$ & $\mathbf{4 6 . 8 1}$ & $\mathbf{3 9 . 1 6}$ & $\mathbf{1 4 8 . 5 6}$ \\
\hline Passive & & & & & \\
\hline Present & 10.53 & 6.31 & 4.26 & 10.15 & 31.25 \\
Past & 1.22 & 37.85 & 11.13 & 1.45 & 51.65 \\
Perfect* & 0.41 & 0 & 0 & 0 & 0.41 \\
Other** & 0 & 0 & 0 & 0 & 0 \\
\hline Subtotal finite verbs per $\mathbf{1 , 0 0 0}$ words & 12.16 & 44.16 & 15.39 & 11.60 & 83.31 \\
\hline Modal & & & & & 13 \\
\hline Active Voice & 2.43 & 0 & 0.65 & 13.05 & 16.13 \\
Passive Voice & 2.03 & 0.63 & 1.96 & 4.35 & 8.96 \\
\hline Subtotal finite verbs per 1,000 words & 4.46 & 0.63 & 2.61 & 17.40 & 25.09 \\
\hline Total finite verbs per 1,000 words & 62.80 & 61.20 & 64.81 & 68.16 & 256.97 \\
\hline
\end{tabular}

*Perfect $=$ Present Perfect

$* *$ Other $=$ Progressive and Past Perfect

Table 8 presents the frequency and distribution of tense and voice across the four moves. The table shows the dominant use of present tense in the active voice (34.44 occurrences per 1,000 words) in Move 1 and Move 4 (31.18 occurrences per 1,000 words). It exceeds the use of the present tense in the active voice in Move 2 (6.94 occurrences per 1,000 words) and Move 3 (15.06 occurrences per 1,000 words). The data also suggest that the present tense in the active voice is frequently used in move 1: Creating a Research Space with 34.44 occurrences per 1,000 words. Move 1, which is the introduction of an abstract, establishes the field of study, prepares for the present research and introduces the current research. In this move it was found that the present active voice is used. A high frequency of present active voice is found in Move 4: Evaluating Results with 31.18 occurrences per 1,000 words. Move 4 evaluates the results by drawing conclusions, comparing results, and indicating discussion. In other words, Move 4 which provides conclusions, results and discussions with present relevance is often written in the present active voice. The higher frequency of active voice in the RA abstracts also conveys a sense of immediacy.

The table also shows that the use of past tense in the active voice is more significant in Move 3 (30.11 occurrences per 1,000 words) which is Summarizing Principal Results exceeding that found in Move 2 (9.46 occurrences per 1,000 words), Move 4 (7.98 occurrences per 1,000 words), and Move 1 (6,48 occurrences per 1,000 words). The Simple Past in the Active Voice is used in this move because it refers to past events and procedures. In Move 3, the past tense in the active voice is the second most frequent tense that marks the summarizing of the principal results. It shows that the experiment happened in the past and thus describing the results should also be in the past. In scientific English, the past tense is used to report the authors' findings or results.

The use of the past passive tense in Move 2 shows a significant frequency ( 37.85 occurrences per 1,000 words) compared to the other tenses in the passive voice. The past passive tense is used 
in this move to indicate the function of reporting procedures and experiments performed. (Biber et al:1998) Move 2: Describing Research Procedure is in the past passive because in this move the writers explain how the research was done and the focus is more on the object rather than the subject. The table shows that the use of Active Voice ( 146.85 occurrences per 1,000 words) is more frequent than the use of the Passive Voice (24.99 occurrences per 1,000 words). The least used tense in the writing of an RA abstract is the Perfect Tense both in the active and passive voice (6.91 occurrences per 1,000 words in active voice and 0.41 occurrences per 1,000 words in the passive voice) and Modals ( 16.13 occurrences per 1,000 words in the active voice and 8.96 occurrences per 1,000 words in the passive voice)

The findings in this research related to the use of tense and voice are compatible with Hardjanto's (1997) suggestion that research article abstracts use finite verbs in the present tense and active voice and are contrary to Graetz's observation that the past tense and passive voice are commonly used in RA abstracts.

\section{CONCLUSION}

The research examined 40 RA abstracts from four journals in Biology, Mechanical Engineering, Linguistics and Medicine in terms of their rhetorical patterns and the use of tenses and voice. The findings of the research show that all of the Medicine RA abstracts have all the 4 moves proposed by Hardjanto (1997). The data also shows that all of the RA abstracts in all disciplines-Biology, Mechanical Engineering, Linguistics and Medicine tended to open with Move 1: Creating a Research Space.

In general it can be concluded that the abstracts in Medicine has all the moves proposed by Hardjanto (1997) unlike the other RA abstracts from Biology which has only one occurrence, Mechanical Engineering has 4 occurrences, and Linguistics which have 4 occurrences of all the moves. Move 1, creating a Research Space, is found in all of the RA abstracts. Biology RA abstracts show that Move 2 which is describing research procedure is not given priority. Mechanical Engineering RA abstracts show that there are two main move patterns used: M1-M2-M3-M4 and M1-M2-M3.The analysis of abstracts across disciplines shows that different disciplines adopted different move structure in the writing of the RA abstracts.

Two tenses that are mostly used in the abstracts are present and past tense both in the active and passive voice. The results show that the present tense in the active voice is frequently used in Move 1 and Move 4. The tense that is least used is the perfect tense and Modal. The past tense in the active voice is frequently used in Move 3, whereas the past passive tense occurs frequently in Move 2 of the RA abstracts.

Concerning the verb tense in each move, the past tense in the active voice is frequently used in Move 3 because it is in this move that the writers summarize the principal results which is used to describe the experiment carried out in the past and the results of the experiment are also largely written in the past tense. It is used to refer to past findings. The past tense in the passive voice is the second most frequent tense used in Mechanical Engineering and Medicine RA abstracts.

By comparing and analyzing the results, it can be seen that the active voice is used more frequently in all the RA abstracts taken from Biology, Mechanical Engineering, Linguistics and Medicine in comparison to the passive voice.

The findings in this study have pedagogical implications for those who would like to know or master the conventions of academic writing in different fields of disciplines and to be familiarize writers of the variations in the writing of RA abstracts: the rhetorical moves and the tenses used in the moves.

\section{REFERENCES}

ANSI. (1979). The American Standard for Writing Abstracts. New York: ANSI Publication.

Bhatia, V.K. (1993). Analyzing Genre: Language Use in Professional Settings. London: Longman.

Biber, D., Conrad, S. \& Reppen, P. (1998) Corpus linguistics: Investigating language structure and use. Cambridge: Cambridge University Press.

Hardjanto, T.D. (1997). Struktur Wacana Intisari Artikel Penelitian dalam Jurnal Ilmiah Berbahasa Inggris. Humaniora V.Yogyakarta: Fakultas Sastra Universitas Gadjah Mada, 114-124. 
Hardjanto, T.D. (1997). Pemakaian Kala dan Diatesis dalam Intisari Artikel Penelitian Ilmiah Berbahasa Inggris. Humaniora VI. Yogyakarta: Fakultas Sastra Universitas Gadjah Mada, 98104.

Huckin, T. (2001). Abstracting from abstracts. In M. Hewings (ed.), Academic Writing in Context: Implications and Applications, pp. 93-103. Birmingham: The University of Birmingham Press.

Hyland, K. (2000). Disciplinary Discourses: Social Interactions in Academic Writing. Harlow: Pearson Education.

Kanoksilapatham, B. (2005). Rhetorical studies of biochemistry research articles. English for Specific Purposes 24(3), 269-292.

Malcolm L. (1987). What Rules Govern Tense Usage in Scientific Articles? English for Specific Purposes Journal 6(1): 31-43.

Salager-Meyer, F. (1992). A text-type and move analysis study of verb tense and modality distribution in medical English abstracts. English for Specific Purposes 11(2), 93-113.

Santos, M. B. (1996). The textual organization of research paper abstracts in applied linguistics. Text, 16(4), 481-499.

Swales, J. (1990). Genre Analysis: English in Academic and Research Settings. Cambridge: Cambridge University Press.

Swales, J. (2004). Research Genres: Explorations and Applications. Cambridge: Cambridge University Press.

Swales, J. M., \& Feak, C. B. (2004). Academic writing for graduate students. (2nd ed.). Ann Arbor: University of Michigan Press.

Thomson Reuters. (2010). Web of Science Arts \& Humanities Citation Index. http://ip-science. thomsonreuters.com/mjl/wos_ahci_a5020 final.pdf. Diakses 10 November 2010.

Thomson Reuters. (2010). Web of Science Science Citation Index Expanded. http://ip-science. thomsonreuters.com/mjl/wos_scie_a5021 final.pdf. Diakses 10 November 2010.

Thomson Reuters. (2010). Web of Science Social Sciences Citation Index. http://ip-science. thomsonreuters.com/mjl/ wos ssci a5022 final.pdf. Diakses 10 November 2010.
Appendix

List of References of Abstracts

\section{A. BIOLOGY}

Yang, Ruolin and Xiangfeng Wang. (2013). Organ Evolution in Angiosperms Driven by Correlated Divergences of Gene Sequences and Expression Patterns. The Plant Cell 25 (1). http://www.plantcell.org/content/25/1/71. abstract. (BIO01)

Fujisawa, Masaki, Toshitsugu Nakano, Yoko Shima, et. al. (2013). A Large-Scale Identification of Direct Targets of the Tomato MADS Box Transcription Factor RIPENING INHIBITOR Reveals the Regulation of Fruit Ripening. The Plant Cell 25 (2). http://www.plantcell.org/ content/25/2/371.abstract. (BIO02)

Erhard, Jr, Karl F., Susan E. Parkinson, Stephen M. Gross, et. al. (2013). Maize RNA Polymerase IV Defines trans-Generational Epigenetic Variation. The Plant Cell 25 (3). http://www. plantcell.org/content/25/3/808.abstract. (BIO03)

Kaltenegger, Elisabeth, Eckart Eich, and Dietrich Ober. (2013). Evolution of Homospermidine Synthase in the Convolvulaceae: A Story of Gene Duplication, Gene Loss, and Periods of Various Selection Pressures. The Plant Cell 25 (4). http://www.plantcell.org/ content/25/4/1213.abstract. (BIO04)

Cheng, Feng, Terezie Mandáková, Jian Wu, et.al. (2013). Deciphering the Diploid Ancestral Genome of the Mesohexaploid Brassica rapa. The Plant Cell 25 (5). http://www.plantcell. org/content/25/5/1541.abstract. (BIO05)

Zhang, Bing, Zhenling Lv, Junling Pang, et.al. (2013). Formation of a Functional Maize Centromere after Loss of Centromeric Sequences and Gain of Ectopic Sequences. The Plant Cell 25 (6). http://www.plantcell.org/content/25/6/1979. abstract. (BIO06)

Ó’Maoiléidigh, Diarmuid S., Samuel E. Wuest, Liina Rae, et.al. (2013). Control of Reproductive Floral Organ Identity Specification in Arabidopsis by the C Function Regulator AGAMOUS. The Plant Cell 25 (7). http://www.plantcell.org/content/25 /7/2482.abstract. (BIO07)

Fu, Yan-Lei, Guo-Bin Zhang, Xin-Fang Lv, et.al. (2013). Arabidopsis Histone Methylase 
CAU1/PRMT5/SKB1 Acts as an Epigenetic Suppressor of the Calcium Signaling Gene $C A S$ to Mediate Stomatal Closure in Response to Extracellular Calcium. The Plant Cell 25 (8). http://www.plantcell.org/content/25/8/2878. abstract. (BIO08)

Lowry, David B., Tierney L. Logan, Luca Santuari, et.al. (2013). Expression Quantitative Trait Locus Mapping across Water Availability Environments Reveals Contrasting Associations with Genomic Features in Arabidopsis. The Plant Cell 25 (9). http:// www.plantcell.org/content/25/9/3266.abstract. (BIO09)

Lu, Zefu, Hong Yu, Guosheng Xiong, et.al. (2013). Genome-Wide Binding Analysis of the Transcription Activator IDEAL PLANT ARCHITECTURE1 Reveals a Complex Network Regulating Rice Plant Architecture. The Plant Cell 25 (10). http://www.plantcell. org/content/25/10/3743.abstract. (BIO10)

\section{B. MEDICINE}

Dodson, John A., Tuyet-Trinh N. Truong, Virginia R. Towle, et.al. (2013). Cognitive Impairment in Older Adults with Heart Failure: Prevalence, Documentation, and Impact on Outcomes. The American Journal of Medicine 126 (2). http://www.amjmed.com/article/S00029343(12)00558-X/abstract. Accessed 11/10/2013. (MED01)

Winter, Anke C., Markus Schürks, Robert J. Glynn, et.al. (2013). Vascular Risk Factors, Cardiovascular Disease, and Restless Legs Syndrome in Women. The American Journal of Medicine 126 (3). http://www.amjmed.com/article/ S0002-9343(12)00868-6/abstract. Accessed 11/10/2013. (MED02)

Stein, Paul D. Fadi Matta. (2013). Treatment of Unstable Pulmonary Embolism in the Elderly and Those with Comorbid Conditions. The American Journal of Medicine 126 (4). http://www. amjmed.com/article/S0002-9343(13)00016-8/ abstract. Accessed 11/10/2013. (MED03)

Gurwitz, Jerry H., David J. Magid, David H. Smith, et.al. (2013). Contemporary Prevalence and Correlates of Incident Heart Failure with Preserved Ejection Fraction. The American Journal of Medicine 126 (5). http://www.amjmed.com/ article/S0002-9343(12)00963-1/abstract. Accessed 11/10/2013. (MED04)
Rautiainen, Susanne, Emily B. Levitan, Murray A. Mittleman, et. al. (2013). Total Antioxidant Capacity of Diet and Risk of Heart Failure: A Population-based Prospective Cohort of Women. The American Journal of Medicine 126 (6). http://www.amjmed.com/article/ S0002-9343(13)00035-1/abstract. Accessed 11/10/2013. (MED05)

Penner, Elizabeth A., Hannah Buettner, Murray A. Mittleman. (2013). The Impact of Marijuana Use on Glucose, Insulin, and Insulin Resistance among US Adults. The American Journal of Medicine 126 (7). http://www.amjmed.com/ article/S0002-9343(13)00200-3/abstract. Accessed 11/10/2013. (MED06)

Ip, Ivan K., Louise Schneider, Steven Seltzer, et.al. (2013). Impact of Provider-led, Technologyenabled Radiology Management Program on Imaging. The American Journal of Medicine 126 (8). http://www.amjmed.com/article/ S0002-9343\%2813\%2900183-6/abstract. Accessed 11/10/2013. (MED07)

Affan Irfan, Tobias Reichlin, Raphael Twerenbold, et.al. (2013). Early Diagnosis of Myocardial Infarction Using Absolute and Relative Changes in Cardiac Troponin Concentrations. The American Journal of Medicine 126 (9). http://www.amjmed.com/article/S00029343\%2813\%2900351-3/abstract. Accessed 11/10/2013. (MED08)

Bangalore, Sripal, Franz H. Messerli. (2013). Gun Ownership and Firearm-related Deaths. The American Journal of Medicine 126 (10). http://www.amjmed.com/ article/S0002-9343\%2813\%2900444-0/ abstract. Accessed 11/10/2013. (MED09)

D’Andrea, Mark A., \& G. Kesava Reddy. (2013). Health Consequences among Subjects Involved in Gulf Oil Spill Clean-up Activities. The American Journal of Medicine 126 (10). HTTP:// http://www.amjmed.com/article/ S0002-9343\%2813\%2900494-4/abstract. Accessed 11/10/2013. (MED10)

\section{LINGUISTICS}

Sze, Felix Yim Binh. (2013). Right dislocated pronominals in Hong Kong Sign Language. Journal of Pragmatics 44 (14). http:// www.sciencedirect.com/science/article/pii/ S0378216612002251.(LIN01) 
Theobald, Maryanne. (2013). Ideas as "possessitives": Claims and counter claims in a playground dispute. Journal of Pragmatics 45. http://www.sciencedirect.com /science/article/pii/S0378216612002378. (LIN02)

Sendra, Verònica Crespo, Constantijn Kaland, Marc Swerts, et. al. (2013). Perceiving incredulity: The role of intonation and facial gestures. Journal of Pragmatics 47. http://www. sciencedirect.com/science/article/pii/ S0378216612002081. (LIN03)

Muntigl, Peter. (2013). Resistance in couples counselling: Sequences of talk that disrupt progressivity and promote disaffiliation. Journal of Pragmatics 49. http://www.sciencedirect.com/science/ article/pii/S0378216613000143. (LIN04)

Yu, Changrong. (2013). Two interactional functions of self-mockery in everyday English conversations: A multimodal analysis. Journal of Pragmatics 50. http://www.sciencedirect. com/science/article/pii/S0378216613000179. (LIN05)

Vandergriff, Ilona. (2013). Emotive communication online: A contextual analysis of computermediated communication (CMC) cues. Journal of Pragmatics 51. http://www.sciencedirect. com/science/article/pii/S037821661300057X. (LIN06)

Schönefeld, Doris. (2013). It is ... quite common for theoretical predictions to go untested (BNC $\mathrm{CMH})$. Aregister-specific analysis of the Englis $\bar{h}$ go un-V-en construction. Journal of Pragmatics 52. http://www.sciencedirect.com/science/ article/pii/S0378216613000040. (LIN07)

Muntigl, Peter, Naomi Knight, Ashley Watkins, et. al. (2013). Active retreating: Personcentered practices to repair disaffiliation in therapy. Journal of Pragmatics 53. http:// www.sciencedirect.com/science/article/pii/ S0378216613000957. (LIN08)

Norén, Niklas. (2013). Pivots constructions as methods for perspective shift during turns at talk. Journal of Pragmatics 54. http://www.sciencedirect.com/science/ article/pii/S0378216612002573. (LIN09)

Hassall, Tim. (2013). Pragmatic development during short-term study abroad: The case of address terms in Indonesian. Journal of Pragmatics 55. http://www.sciencedirect.com/science/article/ pii/S0378216613001240. (LIN10)

\section{MECHANICAL ENGINEERING}

Esteves, Fantina Rosa, Tiago Alexandre Carvalho, António Sérgio Pouzada, Carla Isabel Martins. 2013 The Influence of Processing on the Aesthetic, Morphological and Mechanical Properties of Structural Foam Mouldings of High-Impact Polystyrene. Journal of Mechanical Engineering 59/11, 637-645, SI 133. DOI:10.5545/svjme.2013.997. http://www.sv-jme.eu/data/ upload/2013/11/01_2013_997_Estevez_03. pdf. (ENG01)

Džebo, Elvira, Dušan Žagar, Matjaž Četina, Gregor Petkovšek. (2013). Reducing the Computational Time of the Smoothed Particle Hydrodynamics Method with a Coupled 2-D/3-D Approach. Journal of Mechanical Engineering 59/ ()10, 575-584, SI 115. DOI:10.5545/svjme.2013.944. http://www.sv-jme.eu/data/ upload/2013/10/01_2012_944_Dzebo_04.pdf. (ENG02)

Lyridis, Dimitrios, Panayotis Zacharioudakis, Stylianos Iordanis, Sophia Daleziou. (2013). FreightForward Agreement Time series Modelling Based on Artificial Neural Network Models. Journal of Mechanical Engineering 59/9, 511516, SI 100. DOI:10.5545/sv-jme.2013.947. http://www.sv-jme.eu/data/upload/2013/ 09/02_2013_947_Lyridis_02.pdf. (ENG03)

Dunnen, Steven den, Gert Kraaij, Christian Biskup, Gino M.M.J. Kerkhoffs, et. al. (2013) Pure Waterjet Drilling of Articular Bone: An in vitro Feasibility Study. Journal of Mechanical Engineering 59/7-8, 425-432, SI 81. DOI:10.5545/sv-jme.2012.928. Downloaded 26 Juli 2013 from http://www.sv-jme.eu/ data/upload/2013/07-08/01_2012_928_ Dunnen_03.pdf. (ENG04)

Ostasevicius, Vytautas, Rimvydas Gaidys, Rolanas Dauksevicius, Sandra Mikuckyte. (2013). Study of Vibration Milling for Improving Surface Finish of Difficult-to-Cut Materials. Journal of Mechanical Engineering 59/6, 351357, SI 67. DOI:10.5545/sv-jme.2012.856. Downloaded 26 Juli 2013 from http://www. sv-jme.eu/data/upload/2013/06/01_2012_856_ Ostasevicius_03.pdf. (ENG05)

Ravnikar, Dunja, Primož Mrvar, Jožef Medved, Janez Grum. (2013). Microstructural Analysis of Laser Coated Ceramic Components TiB2 and TiC on Aluminium Alloy EN AW-6082-T651. Journal of Mechanical Engineering 59/5, 281- 
290, SI 55. DOI:10.5545/sv-jme.2012.904. Downloaded 26 Juli 2013 from http://www. sv-jme.eu/data/upload/2013/05/01_2012_904 Ravnikar_03.pdf. (ENG06)

Luo, Ani, Heping Liu, Cheng Li, Yongfan Wang. (2013). Study of a Flowerlike Deployable Structure. Journal of Mechanical Engineering 59/4, 216-222, SI 42 DOI:10.5545/sv-jme.2012.482. Downloaded 26 Juli 2013 from http://www.sv-jme.eu/data/ upload/2013/04/02_2012_482_Luo_03.pdf. (ENG07)

Hudovernik, Matej, Daniel Staupendahl, Mohammad Gharbi, Matthias Hermes, et. al. (2013). 3D Numerical Analysis of 2D Profile Bending with the Torque Superposed Spatial Bending Method. Journal of Mechanical Engineering 59/3, 139147, SI 29. DOI:10.5545/sv-jme.2012.483. Downloaded 26 Juli 2013 from http://www. sv-jme.eu/data/upload/2013/03/01_2012_483_ Hudovernik_03.pdf. (ENG08)

Knez, Luka, Janko Slavič, Miha Boltežar. (2013). A Multi-Axis Biodynamic Measuring Handle for a Human Hand-Arm System. Journal of Mechanical Engineering 59/2, 71-80, SI 15. DOI:10.5545/sv-jme.2012.709. Downloaded 26 Juli 2013 from http://www.sv-jme.eu/data/ upload/2013/02/01_2012_709_Knez_03.pdf. (ENG09)

Florjanič, Blaž, Edvard Govekar, Karl Kuzman. (2013). Neural Network-Based Model for Supporting the Expert Driven Project Estimation Process in Mold Manufacturing. Journal of Mechanical Engineering 59/1, 3-13, SI 3. DOI:10.5545/sv-me.2012.747. Downloaded 26 Juli 2013 from http://www.sv jme.eu/data/ upload/2013/01/01_2012_747_Florjanic_07. pdf. (ENG10) 